\author{
Jurnal Kumara Cendekia \\ https://jurnal.uns.ac.id/kumara
}

\title{
MODEL-MODEL PERMAINAN AUD DI RUMAH (STUDI DESKRIPTIF DI TK AISYIYAH KP DADAP SELAMA MASA PANDEMI COVID-19)
}

\author{
Rahmat Rifai Lubis, Nurhayati Hasibuan, Rina Winarsih, Irawati \\ STAI Sumatera Medan \\ pailubis8@gmail.com,nurhayatihasibuan757@gmail.com, rinawinarsih824@gmail.com, irawati311275@gmail.com
}

\begin{abstract}
Abstrak
Penelitian ini bertujuan untuk menganalisis, (1) model-model permainan AUD di rumah selama masa pandemi Covid-19 di TK Aisyiah Medan, (2) Hambatan yang dialami oleh guru dalam menerapkan kegiatan bermain AUD di rumah selama masa pandemic Covid-19. Penelitian ini dilakukan dengan menggunakan metode penelitian kualitatif berbasis studi deskriptif. Teknik pengumpulan data dilakukan menggunakan teknik Observasi, wawancara, dan dokumentasi. Kesemua teknik pengumpulan data tersebut dilakukan secara online. Adapun hasil penelitian menunjukkan bahwa: (1) Model permainan untuk pengembangan aspek Bahasa di antaranya ialah bercerita pengalaman, dan bernyanyi individu. Model permainan untuk pengembangan aspek sosio emosional ialah permainan tebak raut wajah dan permainan saling berpasangan. Model permainan untuk pengembangan aspek motorik anak ialah permainan engklek dan lompat garis. (2) Adapun hambatan yang dihadapi ialah: hambatan jaringan internet yang membuat akses pembelajaran menjadi terganggu, kurangnya antusias orang tua dalam pembelajaran daring, timbulnya sikap jenuh pada diri anak, kesulitan dalam menilai hasil kegiatan bermain.
\end{abstract}

Kata kunci: Model, permainan, Anak, Covid-19

\begin{abstract}
This study aims to analyze, (1) AUD game models at home during the Covid-19 pandemic at TK. Aisyiah Medan, (2) Barriers developed by teachers in implementing AUD playing activities at home during the Covid-19 pandemic. This research was conducted using qualitative research methods based on descriptive studies. The data technique was carried out using observation, interview, and documentation techniques. All data techniques are carried out online. The results of the study show that: (1) The game model for developing aspects of language includes storytelling and individual singing. The game model for the development of the socio-emotional aspects, namely the facial expression guessing game and pairing games. Game model for the development of motor aspects of children in crank and line jumping games. (2) The barriers that develop: Internet network barriers that make access uninterrupted, lack of enthusiasm from parents in learning, the emergence of boredom in children, difficulties in assessing the results of play activities.
\end{abstract}

Keywords: Model, Games, children, Covid-19 


\section{PENDAHULUAN}

Merebaknya wabah Coid-19 memang memberikan dampak yang sangat signifikan terhadp semua aspek kehidupan manusia, tidak terkecuali aspek pendidikan. Pendidikan yang dahulunya dilakukan secara tatap muka kini berubah menjadi jarak jauh. Pendidikan yang dulu dilakukan di dalam secara bersama-sama, kini berubah menjadi di rumah dan dilakukan secara individu. Intinya banyak terjadi perubahan yang terjadi dalam dunia pendidikan, bahkan menyangkut hal yang mungkin tak pernah terbayangkan sebelumnya. (Khadijah, 2020)

Suka atau tidak suka, mau atau tidak mau semua orang harus mengikuti aturan tersebut, terlebih-lebih anak-anak pada usia sekolah yang sangat rentan dengan penyebaran virus tersebut. (Siagian, 2020). Pada posisi tersebut memang tidak ada pilihan selain belajar jarak jauh atau belajar dari rumah. Disatu sisi orang tua memang khawatir dengan perkembagan kecerdasan anak dengan system jarak jauh tersebut, namun disatu sisi orang tua juga dihadapkan dengan pilihan keselamatan anaknya. Tentu kesalamatan seoarang anak menjadi prioritas utama dalam kehidupan orang tua. (Syah, 2020).

Pada sekolah menengah atas atau juga pada jenjang pendidikan tinggi mungkin kondisi semacam ini tidaklah begitu mempengaruhi, sebab pada usia tersebut mereka sudah dapat belajar mandiri, walau tanpa bantuan intens dari sang guru. Bahkan walaupun mereka tidak pernah belajar secara online, akan tetapi dunia digital sudah sangat akrab dengan kehidupan siswa. Dengan kata lain hanya tinggal penyesuaian sedikit saja. (Dewi, 2020). Namun bagi siswa yang berada pada jenjang di bawahnya terlebih lagi anak usia dini tentu sesuatu yang sangat asing bagi mereka. Kemandirian belajar pada tingkat usia tersebut sangat sulit untuk diterapkan dan dibiasakan, intinya bagi anak usia dini belajar jarak jauh bukan sesuatu yang mudah untuk dilaksanakan. (Ayuni et al., 2020).

Sebagaimana diketahui bahwa pembelajaran pada masa usia dini dikemas dalam bentuk kegiatan bermain. (Fauziddin, 2016). Sebelum masa pandemi Covic-19 datang, bermain lazimnya selalu dilakukan pada ruang terbuka, dan lazimnya juga dilakukan bersama-sama atau berkelompok dengan teman-temannya. Bahkan kegiatan tersebut dilakukan dengan jarak yang sangat dekat dengan siswa lainnya, bergandengan tangan, berlari beriringan dan sebagainya. Intinya sebelum masa Covid-19, bermain dan permainan dapat dilakukan secara bebas dan tanpa ada batasan penghalang apapun. Kini setelah kedatangan wabah Covid-19 seolah 
semuanya berubah, bermain tidak dapat lagi dilakukan dengan bebas dan leluasa seperti sebelumnya. Bahkan hanya dilakukan sendiri atau bersama keluarga di rumah. (Sari et al., 2020).

Kondisi semacam ini terjadi di TK Aisyiyah Kp Dadap, kegiatan bermain dilakukan di rumah dengan dampingan orang tua, guru hanya berperan sebagai sosok yang memberikan bimbingan dan penilaian secara daring. Kondisi keterbatasan ini tentu menjadi kekhawatiran bagi orang tua, terutama dalam hal pencapaian kompetensi yang tidak lagi sepenuhnya di dapat oleh anak. Orang tua mengkhawatirkan bahwa dengan sistem pembelajaran seperti ini, kegiatan bermain tidak lagi menjadi sarana pembelajaran, akan tetapi lebih kepada sarana bersenang-senang semata. Sebab orang tua tentu akan mengalami kendala dalam memanipulasi bermain sebagai sarana belajar sebagaimana yang selama ini dilakukan oleh guru-guru saat di sekolah.

Orang tua juga harus ekstra menguras tenaga dan pikiran mereka untuk memilih permainan yang sesuai dengan situasi dan kondisi anak. Sebab tidak semua jenis bermain dan permainan dapat dilakukan dalam situasi merebaknya wabah Covid-19. Tentu ini merupakan hal yang tak mudah untuk dilakukan, satu sisi ia harus memikirkan kesehatan dan keselamatan anak. dan di satu sisi orang tua juga harus memikirkan bagaimana dengan bermain yang sekedarnya anak tetap mendapatkan kompetensi sebagaimana yang dibutuhkan anak dalam masa perkembangannya. (Rohayani, 2020)

Penelitian sejenis ini pernah dilakukan oleh Khadijah dan Media Gusman dengan judul pola kerjasama guru dan orag tua dalam mengelola bermain anak selama masa pandemi Covid-19. Fokus penelitian ini pada bentuk dan penerapan kerjasama orang tua dan guru dalam merencanakan, melaksanakan, dan mengevaluasi kegiatan bermain anak selama di rumah. (Khadijah, 2020). Bedanya dengan penelitian yang akan dilakukan ini, fokusnya pada bentuk-bentuk permainan yang dipilih oleh guru untuk dilakukan oleh anak dan orang tua di rumah. Penelitian ini tentu memberikan kontribusi yang besar terutama bagi para orang tua dalam menentukan jenis permainan yang sesuai dengan situasi dan kondisi. Sebab selama ini tentu anak-anak tetap bermain di rumah, akan tetapi bermainnya tidak ditekankan untuk penguasaan atau perkembangan kompetensi tertentu yang memang di butuhkan oleh anak.

Untuk memberikan landasan tentang permasalahan ini akan dipaparkan beberapa 
teori yang relevan dengan permasalahan ini. Di antaranya tentang peran permainan dalam kehidupan anak, model permainan berdasarkan aspek pengembangan kecerdasan anak. Penjelasan teori ini di awali dengan pemaparan definisi bermain. Bermain memiliki arti tindakan atau kegiatan sukarela yang dilakukan oleh anak atau sekolompok anak dengan aturan tertentu yang menimbulkan rasa senang, rasa gelisah, cemas dan sebagainya. Bermain sesuatu yang tak dapat dipisahkan dari kehidupan anak, ia sejalan dengan perkembangan usia anak.sigmund freud dengan teori psikoanalisanya mengatakan bahwa bermain ialah sama dengan fantasi dan lamunan. (Khadijah \& Armanila, 2017). Melalui bermain anak dapat memproyeksikan harapan-harapan maupun konflik pribadi, mengeluarkan semua perasaan negative, seperti pengalaman yang tidak menyenangkan trumatik dan harapanharapan yang tidak terwujud dalam realita. Menurut Vigotsky bermain mempunya peranan langsung terhadap perkembangan kognisi anak, anak tidak mampu berpikir secra abstrak, karerna bagi mereka makna dan objerk berbaur menjadi satu, akibatnya anak perlu untuk bermain, karena dari kegiatan bermain anak akan kontak langsung dengan sesuatu objek, dengan sendirinya anak akan dapat memaknai pemikirannya lewat objek yang ada. (Fadlillah, 2019)

Jika bermain lebih diartikan sebagai kegiatan atau pekerjaanya, maka permainan lebih diartikan sebagai jenis, bentuk, atau sistem dari suatu permainan yang ada. Sehingga jika disebut permainan maka identik dengan nama atau sebutan dari bentuk permainan. Ada banyak ragam permainan yang ada, kemunculannya berdasarkan pada kreativitas atau perkembangan dari permainan-permainan sebelumnya. Semakin bertambah masa tidak menutup kemungkinan satu jenis permainan akan bertambah atau tidak juga menutup kemungkinan permainan itu hilang. (Elfiadi, 2016).

Bermain memiliki peran yang sangat penting bagi kehidupan seorang anak, selain memang merupakan kebiasaan anak, bermain juga merupakan sarana untuk mengembangkan potensi, dan kecerdasan seorang anak. Menghalangi anak dari bermain itu sama halnya dengan merusak perkembangan anak. (R. R. Lubis, 2018b). karena tidak dapat dipungkiri lewat kegiatan bermain anak terlibat aktif dengan segala bentuk kegiatan yang secara langsung atau tak langsung dapat mengembangkan kemampuan yang dimilikinya.(Priyanto, 2014). 
Perkembangan yang dimaksud ialah perkembangan kognitif, perkembangan Bahasa, perkembagan seni, perkembangan sosio dan emosional, perkembangan spiritual, perkembagan motorik halus dan kasar. Perkembangan ini menjadi prioritas dicapai pada masa usia dini sebab sama-sama diketahui secara teoritis pada masa ini merupakan masa Golden Age atau masa keemasan. (Uce, 2017). Bermain merupakan sarana untuk mengembangkan kecerdasan sebagaimana yang telah disebutkan sebelumnya. Tetapi dalam hal pengembangan kecerdasan anak, maka jenis permainan perlu untuk dirancang sedemikian rupa, sehingga memberikan kemudahan dan ruang untuk kecerdasan anak tersebut.

Adapu model-model permainan untuk tingkat AUD yang disesuaikan dengana aspek perkembagannya sebagai berikut: (Anggreni, 2014).

- Permaianan pengembangan aspek kognitif. Permainan untuk aspek ini menekankan pencapaian pada aspek kognisi, dimana permainan dianggap sebagai sarana bagi anak untuk mensinkronisasi pemikirnnya yang abstrak. Pada masa usia dini tentu anak tidak dapat berpikir secara absrtak, ia akan mudah mencerna sesuatu tatkala objek yang diamatinya terwujud secara nyata. Misalnya sang anak akan dapat mendeskripsikan hewan kuda tatkala ia langsung melihat kuda dan ikut bermain bersamanya. (R. R. Lubis, 2018a).

- Permainan pengembangan aspek Bahasa. Dalam kegiatan bermain tentu salah satu unsur yang harus ada ialah komunikasi.Komunikasi dipergunakan untuk berbicara tentang konsep dari permainan, aturan dari permainan, dan mengatur alur permainan. Dalam hal ini secara tidak langsung anak akan dipaksa untuk berkomunikasi dengan lawan mainnya, dan dipaksa dalam komunikasinya lawan mainnya dapat memahami komunikasi yang di utarakan.

- Permainan pengembangan aspek sosio emosional. Dalam kegiatan bermain anak akan berinteraksi dengan lingkungan, teman, dan lawan bermain. Interaksi ini membuat siswa mendapatkan pemahaman tentang bagaimana bersosialisasi kepada orang lain, dan belajar bagaimana menguasai diri sehingga dapat diterima oleh orang lain. Jika hal ini terjadi maka secara perlahan anak akan dapat turut serta dalam bermasyarakat kelak, dan mengontrol diri ketika berada di manapun

- Permainan pengembangan aspek motorik. Kegiatan bermain tentu 
melibatkan kemampuan fisik anak, keterlibatan fisik anak ini tentu akan membuat anak secara tidak langsung bergerak aktif, dengan sendirinya perkenbangan kecerdasan motorik anak akan terfasilitasi.

Berdasarkan hal-hal di atas maka peneliti tertarik untuk melakukan penelitian terkait dengan bentuk-bentuk permainan yang dilakukan anak sesuai dengan anjuran yang diperintahkan oleh guru. Secara khusus penelitian ini bertujuan untuk mengetahui bentuk-bentuk permainan selama pandemic Covid-19 di TK Aisyiah Kp. Dadap Medan, Hambatan yang dihadapi dalam mengelola bermain anak di rumah.

\section{METODE PENELITIAN}

\section{a. Lokasi dan Waktu Penelitian}

Penelitian ini menggunakan metode Kualitatif berbasis studi dekriptif. Studi deskriptif bermaksud untuk menggambarkan kejadian atau fenomena apa adanya, dalam arti sesuai dengan fakta dan kejadian yang terjadi pada objek penelitian. Dalam hal ini peran dari interpretasi sang peneliti sangat dominan sebab proses penelitian akan lebih banyak melibatkan kegiatan wawancara dan observasi. (M. Lubis et al., 2020)

Menurut Creswell penelitian berbasis studi deskriptif berfokus untuk mengutarakan kejadian atau fenomena yang dianggap relevan untuk di angkat kepermukaan dengan alasan urgensi dan sisi kekhasan suatu peristiwa. Sugiyono menjelaskan bahwa kegiatan deskriptif juga disertai dengan kegiatan analisis dari sang penliti, hal ini bertujuan untuk lebih mehami peristiwa dan kejadian dari berbagai sudut pandang. (Creswell, 2018). (Sugiyono, 2018),

Penelitian ini dilaksanakan di TK Aisiyah Kp. Dadap yang beralamat di Jl. Mustafa No. 1 Medan. Alasan pemilihan lokasi ini ialah TK Aisyiah selama ini menerapkan pembelajaran jarak jauh berbasis daring (dalam jaringan) dimana rata-rata kegiatan belajar di kemas dalam bentuk bermain. Dan kegiatan bermain tersebut memang di monitoring oleh guru dengan cara siswa di minta untuk memberikan laporan kegiatan dalam bentuk video atau vido call langsung kepada guru.

Penelitian ini dilaksanakan mulai dari bulan agustus hingga September 2020. Dikarenakan Covid-19 penelitian ini dilaksanakan dengan waktu yang fleksibel dalam arti menyesuaikan dengan kondisi dan situasi informan penelitian. Dapat dikatakan tidak ada waktu yang pasti untuk melakukan pengumpulan data, bias saja terjadi di selasela pembelajaran daring berlangsung, atau 
juga terjadi diluar jam pembelajaran, dan kadang kala juga bisa terjadi pada malam hari

\section{b. Teknik pengumpulan data}

Pengumpulan data dilakukan dengan menggunakan beberapa teknik seperti yang tertera di bawah ini:

- Observasi

Observasi dilakukan dengan cara observasi terhadap kegiatan bermain yang dilakukan oleh anak yang di damping oleh orang tua siswa. Namun observasi ini bersifat tidak langsung, observasi ini dilakukan dengan cara mengamati tugas video pembelajaran yang dikirim oleh orang tua siswa kepada gurunya. Atau bisa juga dilakukan saat pembelajaran daring berlangsung menggunakan video call atau Zoom berlangsung.

- Wawancara

Wawancara dilakukan kepada guru, siswa, dan orang tua di TK Aisyiah Kp. Dadap Medan. Wawancara dilakukan untuk memperoleh informasi terkait dengan bentukbentuk permainan, dan bagaimana respon orang tua terhadap kendala yang mereka hadapi selama mendampingi anak dalam kegiatan bermain tersebut. Kepada guru peneliti berwawancara bagaimana sang guru memberikan solusi terhadap permasalahan yang dihadapi oleh orang tua.

- Dokumentasi

Dokumentasi dilakukan terhadap hasil penilaian guru terhadap kegiatan bermain siswa. Dalam hal ini tentu guru selalu memberikan penilaian terhadap tugas yang telah diselesaikan oleh anak-anak, dan memberikan laporan tertulis terhadap hasil penilaian tersebut. Dokumetasi laporan penilaian tersebutlah yang kemudian dianalisis untuk dilihat keterkaitannya dengan penelitian.

\section{c. Teknik analisis data}

Teknik analisis data dalam penelitian ini menggunakan teknik analisis deskkriptifinduktif. Dalam arti temuan-temuan penelitian yang bersifat khusus lantas di analisis dengan cara mendeskripsikannya menggunakan interpretasi penulis. Walaupun penelitian ini menggunakan interpretasi si penulis, namun interpretasi di usahakan tetap berpijakan pada temuan penelitian yang ada. (R. R. Lubis et al., 2020).

\section{HASIL DAN PEMBAHASAN}

\section{a. Bentuk-Bentuk Permainan Selama Pandemi Covid-19}


Seperti yang telah disebutkan sebelumnya bahwa permainan pada masa pandemi Covid-19 menjadi terbatas dan tidak leluasa di lakukan oleh anak. Di bawah ini akan di kemukakan beberapa bentuk permainan selama masa Covid-19, perincian permainan akan disesuaikan dengan jenis kompetensinya:

\section{Permainan pengembangan aspek kognitif AUD}

Bentuk permainan yang akan di kemukakan di bawah ini merupakan bentuk permainan yang menekankan pada aspek kognitif AUD. Aspek ini menjadi utama untuk dikembangkan mengingat pada masa usia dini perkembangan kecerdasan otak anak berada pada masa golden Age. Untuk aspek pengembangan kognitif ini ada beberapa jenis permainan yang dilakukan di TK Aisiyah Kp. Dadap yakni:

- Menggunting dan menempel pola Jenis permainan ini untuk mengasah kognitif anak dalam mengenal pola bangun ruang sebagaimana yang sering mereka temukan dalam kehidupan sehari hari. Pola yang dimaksud seperti lingkaran, persegi, segitiga, kerucut dan sebagainya. Jenis permainan ini dicontohkan oleh sang guru terlebih dahulu dengan cara mengirimkan video pembelajaran yang berisi tugas kepada peserta didik lewat group whatsapp yang telah di buat sebelumnya. Dari observasi peneliti, tampak bahwa sang guru memberikan contoh dengan cara pembuatanyya langkah demi langkah lalu kemudian meminta siswa untuk melakukannya bersama dengan orang tua di rumah dan mengirimkan video kegiatannya kepada guru tersebut. Pengerjaan tugas ini diberi limit waktu mencapai satu minggu lamanya.

Hasil wawancara penulis dengan salah seorang guru di TK Aisyiyah bernama ibu siti mengatakan bahwa pemilihan bermain menggunting dan menempel pola dikarenakan permainan itu sangat memungkinkan di lakukan oleh anak dan orang tua di rumah. Orang tua dan anak samasama mencari pola-pola tersebut di dalam majalah, koran ataupun buku-buku bekas lainnya, atau juga bisa saja pada bekas kemasan-kemasan makanan atau produk lainnya, Selain memberikan rasa senang kepada siswa, jenis permainan ini juga secara tak langsung mengasah kecerdasan kognitif siswa.

- Permainan congklak

Guru memberikan arahan kepada peserta didik (dalam hal ini didampingi oleh orang tua) lewat komunikasi video call. Melalui komunikasi ini guru memberikan arahan tentang teknis pelaksanaan permainan 
kepada sang anak, dan memberikan arahan kepada orang tua terkait dengan perkembangan kognisi anak, dalam hal ini orang tua di minta untuk tidak hanya sekedar mendampingi anak bermain saja, melainkan mendampingi anak untuk dapat sistematis dan terampil dalam mengambil keputusan dan memecahkan masalah.

Jenis permainan ini untuk mengasah kognitif anak dalam hal mengenal urutan, dan hitungan, selain itu permainan ini juga mengasah keterampilan untuk berpikir sistermatis dan pemecahan masalah. Disebut membuat anak mampu mengenal urutan dan sistematis karena permainan ini menghendaki anak untuk mampu memahami urutan-urutan lumbung yang akan di isi oleh 'buah congklak'. Disebut mampu mengatasi keterampilan berpikir pemecahan masalah karena permainan ini menghendaki anak untuk dapat mengambil keputusan lumbung mana yang hendak dipilih terlebih dahulu untuk memulai permainan. Dalam memilih permainan tersebut sang anak harus mampu untuk memperkirakan kemenangannya. Di bawah ini gambar menunjukkan aktivitas siswa bermain congklak:

\section{Gambar 1 \\ Orang Tua Mendampingi Anak Bermain Conklak}

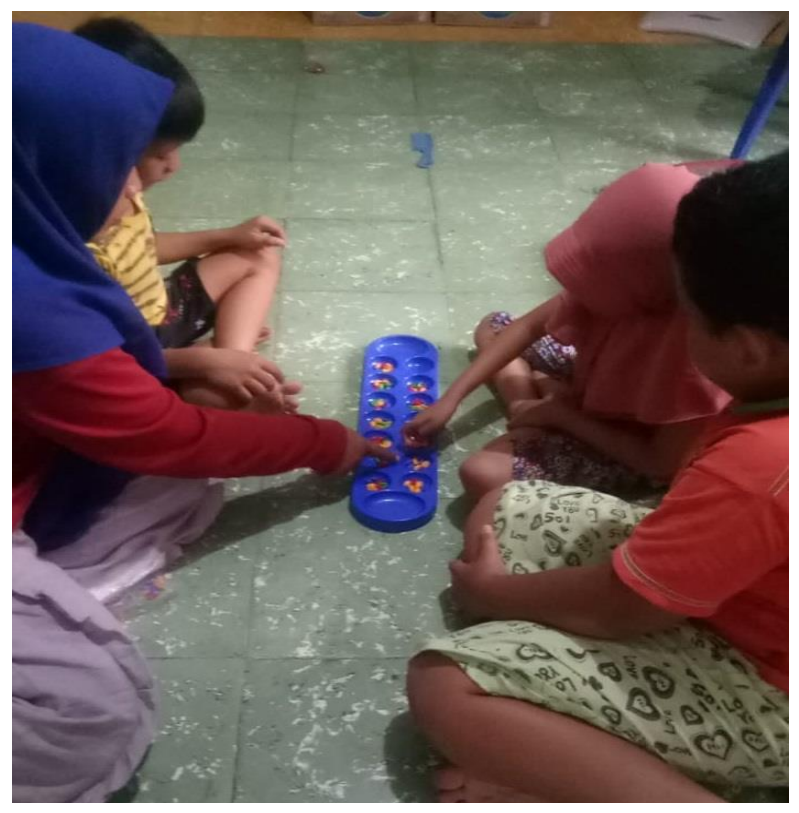

\section{Permainan Pengembangan Aspek Bahasa AUD}

Peningkatan kecerdasan Bahasa juga menjadi perhatian guru TK Aisyiah Medan sebab memang pada masa ini beberapa anak terbilang rentan dengan gangguan berbicara. Pada masa ini anak harus banyak dilibatkan berkomunikasi dengan orang lain agar keterampilan bahasanya meningkat. Beberapa kegiatan bermain yang dilakukan oleh anak-anak di TK Aisyiah ini ialah sebagai berikut:

- Bercerita pengalaman

Permainan ini memang terkesan tidak seperti permainan yang membutuhkan mekanisme dan sistem tersendiri sebagaimana lazimnya karekteristik 
permainan. Permainan ini hanya sekedar dalam bentuk kegiatan bercerita pengalaman yang ditanyakan oleh guru terkait dengan pengalamannya pada hari libur selama masa covid-19, biasanya yang di tanyakan seputar kegiatan yang dilakukan, dan bersama dengan siapa kegiatan tersebut itu dilakukan.

Bercerita pengalaman ini langsung dilakukan guru saat berkomunikasi dengan guru lewat video call, atau bahkan terkadang juga melalui aplikasi zoom. Orang tua dalam hal ini memberikan dampingan dan bantuan pemilihan kosa kata pada saat anak bercerita, sebab pada saat bercerita sering sekali anak kesulitan dalam pemilihan kosa kata yang tepat. Dalam hal ini anak terkadang paham dengan yang akan disampaikan namun terkadang sulit untuk mengungkapkannya dengan kata-kata.

Kegiatan ini disebut dengan permainan karena anak dalam hal ini bercerita dikemas dengan canda dan humor baik dari guru maupun orang tua. Sehingga terkesan tidak memberikan beban kepada anak untuk mengutarakan pengalamannya. Bahkan terkadang bercerita juga di kemas dengan nyanyian dari guru ataupun dari siswa itu sendiri. Kegiatan ini tentu secara tidak langsung mengembangkan keterampilan berbicara siswa.

- Bernyanyi individu
Permainan ini dikemas dalam bentuk hafalan lagu yang di contohkan oleh guru lewat komunikasi video call atau zom berasama-sama dengan teman lainnya. Laglagu yang di bawakan oleh siswa pada dasarnya adalah lagu yang asing ditelinga mereka. Tujuan pemilihan asing tersebut untuk lebih memberikan penekanan pengembangan aspek Bahasa siswa. Agar terkesan tidak menunjukkan sesuatu yang membebani siswa dengan hafalan lagu, lagulagu yang dipilih dengan tema-tema yang membuat siswa menjadi riang, dan liriknya pun terbilang cukup singkat, sehingga memudahkan siswa untuk menghafalnya dalam waktu yang singkat.

\section{Permainan Pengembangan Aspek Sosial Emosional AUD}

Pengembangan aspek social dan emosional pada masa pandemic Covid 19 menjadi perhatian serius guru dan orang tua. Sebab fenomena menunjukkan bahwa banyak terjadi perubahan pada sikap dan emosional anak selama pembelajaran dari rumah, terutama pada hal emosional mereka yang semakin hari semakin menunjukkan sikap jenuh dan acuh tak acuh untuk mengikuti pembelajaran. Hal ini sebenarnya dikarenakan model pembelajaran jarak jaih yang tidak memungkinkan guru untuk mengawasinya dari dekat, sehingga anak 
merasa bahwa apapun yang mereka lakukan tentu tidak akan mendapatkan punishment atau apaun dari guru mereka. Untuk mengatasi ini beberapa jenis permainan yang dilakukan siswa sebagai bentuk pengembangan kecerdasan sosial dan emosional siswa ialah sebagai berikut:

- Permainan tebak raut wajah

Permainan ini di TK Aisyiah menurut guru bermula dari munculnya sifat siswa yang terkadang enggan untuk mengikuti kegiatan pembelajaran lewat komunikasi daring. Beberapa siswa merasa tidak mood atau 'merajuk' enggan mengikuti pembelajaran. Dalam keadaan ini biasanya siswa dengan raut wajah yang berbeda-beda, ada dengan raut wajah marah, ada dengan raut wajah benci, ada raut wajah yang acuh tak acuh dan sebagainya. Sehingga sang guru di TK tersebut tertarik untuk membuat permainan tebak raut wajah. Harapannya dengan permainan ini sang siswa mengetahui bagaimana raut wajah mereka saat enggan mengikuti pembelajaran, sehingga dengan begitu dapat berubah dan menjadi tertarik kembali untuk belajar.

Permainan ini dikemas dengan canda dan humor oleh guru. Ketika guru memberikan gambar raut wajah seseorang maka sering kali direspon dengan humor dan tertawaan oleh siswa, karena mereka menganggap bahwa raut wajah tersebut lucu. Ada juga siswa yang meresponnya dengan takut dan terkejut. Pada kondisi inilah sang guru memberikan masukan kepada siswa nya untuk selalu bersemangat mengikuti pembelajaran sebab kalau tidak anak-anak akan memiliki wajah yang sama seperti pada gambar yang telah ditunjukkan.

- Permainan saling berpasangan

Jenis permainan ini juga digunakan oleh guru-guru di TK Aisyiah untuk meningkatkan kemampuan sosial siswa. Permainan ini dilakukan oleh dua orang, dalam hal ini dua orang tersebut ialah anak dan orang tuanya. Keduanya berpasangan untuk melakukan permainan saling mencocokkan. Bisa dalam bentuk tarian yang sama, nyanyian yang sama, ataupun gerakan unik yang sama. Yang terpenting dalam jenis permainan ini harus ada kesamaaan, sehingga menunjukkan kekompakkan dan keserasian.

\section{Permainan Pengembangan Aspek Motorik AUD}

Pengembangan motoric juga tak kalah pentingnya bagi anak usia dini sebab pada masa usia tersebut anggota tubuh anak mengalami perkembangan yang pesat. Pembelajaran yang baik tentu yang memberikan ruang kepada anak untuk mengembangkan seluruh aspek dalam kedirian siswa. Beberapa jenis permainan 
untuk pengembangan aspek motorik AUD ialah sebagai berikut:

- Permainan lompat garis

Permainan ini terbilang sederhana, dan dapat dilakukan di rumah bersama dengan orang tua di rumah masing-masing. Caranya orang tua cukup memberikan batasan-batasan garis di lantai, lantas meminta anaknya untuk melompat hingga melewati garis yang telah di buat. Kalau terdapat lima garis yang diberikan, maka sang anak harus melompat sebanyak lima garis tersebut. Kegiatan ini tentu dapat memberikan ruang bagi otot kaki sehingga dapat bergerak dengan teratur.

Permainan ini kemudian direkam dan dikirimkan kembali kepada guru, lantas kemudian sang guru memberikan penilaian terhadap video yang sudah dikirimkan. Hal yang terpenting dalam kegiatan lompa garis ini ialah bukan pada keberhasilan anak dalam melompati garis akan tetapi lebih kepada sikap anak yang merasa senang dan pemberian kesempatan pada otot-otot anak untuk bergerak, sehingga memberikan ruang bagi pengembangan motorik anak.

- Permainan engklek

Permainan ini juga hampir sama dengan permainan lompat garis, hanya saja pada permainan ini kegiatan melompat pada pola yang sudah ditentukan jenis gerakannya. Kegiatan bermain engklek ini juga tidak hanya mengembangkan kecerdasan motoric anak, akan tetapi juga mengembangkan kecerdasan kognitif anak, sebab dalam kegiatan ini anak harus menggunakan pengetahuan dan ingatannya untuk setiap pola yang dilalui.

Permainan engklek ini direkam oleh orang tua dan dikirim kepada guru dalam bentuk video, untuk tidak menimbulkan kejenuhan, permainan ini dapat saja dilakukan bersama dengan kakak, atau abangnya yang ada di rumah, bahkan dari hasil pengamatan yang penulis lakukan kegiatan ini juga kadang kala dilakukan bersama dengan orang tua.

\section{b. Hambatan yang dihadapi dalam mengelola bermain anak di rumah.}

Walaupun kegiatan tersebut terbilang kegiatan bermain tetapi dalam pelaksanaanya guru-guru TK Aisyiah mengalami beberapa hambatan. Hambatan tersebut tidak serta merta karena kesalahan orang tua atau siswa, kadang kala juga dikarenakan kondisi, sarana dan alat bermain yang terkadang tidak mendukung terlaksananya kegiatan bermain. Untuk lebih rinvinya hambatan yang dihadapi guru dalam mengelola kegiatan 
bermain anak selama masa pandemi covid-19 ialah sebagai berikut:

- Hambatan jaringan internet, hambatan ini menjadi hambatan utama yang kerap muncul saat pembelajaran daring berlangsung, sehingga kadang kala informasi mengenai arahan permainan tidak tersampaikan secara utuh oleh guru dan tidak dapat diterima juga secara utuh oleh orang tua. Sehingga dampaknya ialah terjadi mis komunikasi, atau kesalah pahaman dalam memahami informasi.

- Kurangnya anrusias orang tua dalam pembelajaran daring, hambatan ini muncul dengan alasan yang beragam dari orang tua. Mulai dari alasan kesibukan, alasan pekerjaan, dan sebagainya. Membuat orang tua akhirnya tidak begitu aktif dalam mengikuti pembelajaran yang dilakukan. Tentu saja muaranya beberapa orang tua tidak ikut melakukan kegiatan bermain, sebagaimana yang dilakukan oleh teman-temannya.

- Timbulnya sikap jenuh pada diri anak, sikap ini tentu menjadi hambatan kepada guru dan orang tua untuk mengikut sertakan anaknya dalam pembelajaran daring, kerap kali yang terjadi orang tua selalu bersusah payah untuk membujuk anaknya ikut serta dalam kegiatan pembelajaran daring. Sikap jenuh ini memang dikarenakan oleh beberapa hal seperti, ketidak sukaan anak dengan jenis permainan, atau rasa kesulitan dalam penerapan kegiatan bermain tersebut.

- Kesulitan dalam menilai hasil kegiatan bermain, penilaian menjadi hambatan terberat yang dialami hampir setiap guru di TK Aisyiah. Kesulitan yang terjadi ialah rata-rata kemampuan anak melakukan kegiatan bermain tersebut $60 \%$ dampingan dari orang tua, hanya sekitar $40 \%$ saja yang permainan itu dilakukan oleh anak sendiri (khusus untuk kegiatan bermain individu). Seperti bernyanyi misalnya dalam hal ini orang tua yang lebih banyak menghafal lirik di banding dengan anaknya. Kesulitan ini terkadang membuat guru tidak 
objektif dalam memberikan penilaian, akibatnya sering sekali penilaian hanya dalam bentuk ucapan lisan semata. Dalam hal laporan penilaian sebagaimana lazimnya saat sebelum masa pandemi tidak tampak dilakukan pada masa pandemi.

\section{PENUTUP}

Kegiatan bermain berperan bukan hanya sekedar memberikan kesenangan pada anak, akan tetapi kegiatan bermain juga dapat mengembangkan aspek kecerdasan anak. Seperti kecerdasan kognitif, kecerdasan Bahasa, kecerdasan sosio emosional, kecerdasan motorik. Dalam hal pengembangan kecerdasan itu terdapat beberapa model permainan yang diterapkan di TK Aisyiah Medan, yakni untuk pegembangan aspek kognitif permainan yang diterapkan ialah permainan tebak congklak menggunting dan menempel pola. Untuk pengembangan aspek Bahasa permainan yang diterapkan ialah bercerita pengalaman, dan bernyanyi individu. Untuk pengembangan aspek sosio emosional permainan yang diterapkan ialah permainan tebak raut wajah dan permainan saling berpasangan. Dan untuk pengembanfan aspek motoric anak permainan yang diterapkan ialah permainan engklek dan lompat garis. Namun penerapan permainan itu juga menuai beberapa kendala. Adapun kendala yang dimaksud ialah: (1) hambatan jaringan internet yang membuat akses pembelajaran menjadi terganggu, (2) kurangnya antusias orang tua dalam pembelajaran daring, hambatan ini muncul dengan alasan yang beragam dari orang tua, seperti kesibukan, pekerjaan, dan sebagainya. (3) Timbulnya sikap jenuh pada diri anak, sikap ini tentu menjadi hambatan kepada guru dan orang tua untuk mengikut sertakan anaknya dalam pembelajaran daring, (4) Kesulitan dalam menilai hasil kegiatan bermain.

Berdasarkan pemaparan di atas beberapa rekomendasi:

1. Guru, model perminan perlu bervariasi agar siswa menjadi tidak jenuh selama pembelajaran di rumah

2. Orang tua, kegiatan bermain perlu mendapatkan pendampingan dari orang tua, sebab jika tidak maka kegiatan bermain tidak akan memberikan dampak pengalaman belajar bagi anak.

3. Pengelola pendidikan, kegiatan bermain sesuatu cara anak untuk belajar, walau di tengah kondisi pembelajaran jarak jauh 
pembelajaran tetap harus

dilaksanakan. Namun dengan pola yang berbeda satu sama lain.

\section{DAFTAR PUSTAKA}

Anggreni, M. A. (2014). Metode Bermain Untuk Mengembangkan Kecerdasan Anak Usia Dini. Buana Pendidikan: Jurnal Fakultas Keguruan Dan Ilmu Pendidikan, 10(18).

Ayuni, D., Marini, T., Fauziddin, M., \& Pahrul, Y. (2020). Kesiapan Guru TK Menghadapi Pembelajaran Daring Masa Pandemi Covid-19. Jurnal Obsesi: Jurnal Pendidikan Anak Usia Dini, 5(1), 414-421.

Creswell, J. w. (2018). Penelitian Kualitatif dan Desain Riset; Memilih di Antara Lima Pendekatan (5th ed.). Pustaka Pelajar.

Dewi, W. A. F. (2020). Dampak Covid-19 Terhadap Implementasi Pembelajaran Daring Di Sekolah Dasar. Edukatif: Jurnal Ilmu Pendidikan, 2(1), 55-61. https://doi.org/https://doi.org/10.31004/ edukatif.v2i1.89

Elfiadi, E. (2016). Bermain dan Permainan Bagi Anak Usia Dini. ITQAN: Jurnal Ilmu-Ilmи Kependidikan, 7(1), 51-60.

Fadlillah, M. (2019). Buku ajar bermain \& permainan anak usia dini. Prenada Media.

Fauziddin, M. (2016). Pembelajaran Agama Islam Melalui Bermain Pada Anak Usia Dini. Jurnal Obsesi: Jurnal Pendidikan Anak Usia Dini, 2(2), 107-116.

Khadijah, \& Armanila. (2017). Bermain dan Permainan Anak Usia dini. Perdana Publishing.

Khadijah, K. (2020). Pola Kerja Sama Guru Dan Orangtua Mengelola Bermain Aud Selama Masa Pandemi Covid-19.
Kumara Cendekia, 8(2), 154-170.

Lubis, M., Yusri, D., \& Gusman, M. (2020). Pembelajaran Pendidikan Agama Islam Berbasis E-Learning (Studi Inovasi Pendidik MTS. PAI Medan di Tengah Wabah Covid-19). Fitrah: Journal of Islamic Education, 1(1), 1-15.

Lubis, R. R. (2018a). Identifikasi Perilaku Dan Karakteristik Awal Peserta Didik (Konsep dan Pola Penerapan Dalam Desain Instruksional). Hikmah, 15(1), 7.

Lubis, R. R. (2018b). Optimalisasi Kecerdasan Spiritual Anak. Jurnal AlFatih, 1(1), 1-18.

Lubis, R. R., Dalimunthe, R. A., \& Efendi, R. (2020). Reduksi Perilaku Bolos Sekolah (Studi Tentang Kerja Sama Guru PAI dan IPS di MTs PAI Medan). Intiqad: Jurnal Agama Dan Pendidikan Islam, 12(1).

Priyanto, A. (2014). pengembangan kreativitas pada anak usia dini melalui Aktivitas bermain. Jurnal Ilmiah Guru Caraka Olah Pikir Edukatif, 2.

Rohayani, F. (2020). Menjawab Problematika yang Dihadapi Anak Usia Dini di Masa Pandemi Covid-19. Qawwam, 14(1), 29-50.

Sari, D. A., Mutmainah, R. N., Yulianingsih, I., Tarihoran, T. A., \& Bahfen, M. (2020). Kesiapan Ibu Bermain Bersama Anak Selama Pandemi Covid19,"Dirumah Saja." Jurnal Obsesi: Jurnal Pendidikan Anak Usia Dini, 5(1), 475-489.

Siagian, T. H. (2020). Mencari Kelompok Berisiko Tinggi Terinfeksi Virus Corona Dengan Discourse Network Analysis. Jurnal Kebijakan Kesehatan Indonesia: JKKI, 9(2), 98-106.

Sugiyono. (2018). Metode Penelitian Kuantitatif, Kualitatif, dan $R \& D$ (10th ed.). Alfabeta. 
Syah, R. H. (2020). Dampak Covid-19 pada Pendidikan di Indonesia: Sekolah, Keterampilan, dan Proses Pembelajaran. SALAM: Jurnal Sosial Dan Budaya Syar-I, $\quad 7(5), \quad 395-402$. https://doi.org/10.15408/sjsbs.v7i5.153 14

Uce, L. (2017). The golden age: Masa efektif merancang kualitas anak. Bunayya: Jurnal Pendidikan Anak, 1(2), 77-92. 
KUMARA CENDEKIA Vol. 8 No. 3 Bulan September 2020 